\title{
Rectal Temperature, Calving-Related Factors, and the Incidence of Puerperal Metritis in Postpartum Dairy Cows
}

\author{
M. E. Benzaquen, ${ }^{*}$ C. A. Risco, ${ }^{* 1}$ L. F. Archbald, ${ }^{*}$ P. Melendez, ${ }^{\star}$ M.-J. Thatcher, ${ }^{\star}$ and W. W. Thatcher† \\ *Department of Large Animal Clinical Sciences, College of Veterinary Medicine, and \\ †Department of Animal Sciences, University of Florida, Gainesville 32610
}

\begin{abstract}
The objectives of this study were as follows: 1) to evaluate the association among abnormal calving, parity, and season on the incidence of puerperal metritis $(\mathrm{PM})$ and clinical endometritis (CE) during $\mathrm{d} 3$ to 13 and 20 to 30 postpartum, respectively; 2) to describe the rectal temperature (RT) of cows with PM before diagnosis; and 3) to document associations among PM, $\mathrm{CE}$, and reproductive performance in lactating dairy cows. This study followed a prospective observational study design. Cows were classified as having an abnormal calving status (AC), i.e., cows calving with dystocia, twins, retained fetal membranes, or some combination of these conditions, and having a normal calving status (NC). Daily RT was recorded from d 3 to 13 postpartum for all cows, and health examinations were performed on cows that appeared not well. A total of 450 calvings were evaluated. Cows with an AC had greater odds of PM than cows with NC [adjusted odds ratio $(\mathrm{AOR})=4.8 ; 95 \%$ confidence interval $(\mathrm{CI})=2.9$ to 8.0). A season by parity interaction showed that primiparous cows that calved during the warm season had lower AOR of PM than during the cool season (0.24; $95 \% \mathrm{CI}=0.09$ to 0.62$)$, whereas multiparous cows did not have seasonal effects on PM $(1.43 ; 95 \%$ $\mathrm{CI}=0.65$ to 3.18). Cows with $\mathrm{AC}$ have greater $\mathrm{AOR}$ for $\mathrm{CE}$ than cows with $\mathrm{NC}(2.8 ; 95 \% \mathrm{CI}=1.7$ to 4.9$)$, and greater $\mathrm{AOR}$ of $\mathrm{CE}$ were detected in cows diagnosed with PM than in cows without PM $(2.2 ; 95 \%$ $\mathrm{CI}=1.1$ to 3.9 ). Rectal temperature in cows with PM increased significantly $24 \mathrm{~h}$ before diagnosis of PM, reaching $39.2 \pm 0.05^{\circ} \mathrm{C}$ on the day of diagnosis. In cows with PM and fever at diagnosis, the RT began to increase from 72 to $48 \mathrm{~h}$ before the diagnosis of PM and continued to increase to $39.7 \pm 0.09^{\circ} \mathrm{C}$ on d 0 (day of diagnosis). Nonetheless, cows with PM without fever at diagnosis had no daily increases in RT before diag-
\end{abstract}

Received July 27, 2006.

Accepted December 19, 2006.

${ }^{1}$ Corresponding author: riscoc@mail.vetmed.ufl.edu nosis of PM. Still, the RT on d 0 was different from cows without PM. Cows without PM had a stable RT $\left(38.6 \pm 0.01^{\circ} \mathrm{C}\right)$. There were no detected differences in first-service conception risk or cumulative pregnancy risk by $150 \mathrm{~d}$ postpartum between cows with or without PM. Still, a season effect on first-service conception AOR (warm vs. cool $=0.98 ; 95 \% \mathrm{CI}=0.18$ to 0.72 ) and accumulated pregnancy AOR by $150 \mathrm{~d}$ postpartum was detected (warm vs. cool $=0.18 ; 95 \% \mathrm{CI}=0.10$ to 0.33 ). Key words: metritis, temperature, monitoring, dairy

\section{INTRODUCTION}

Puerperal metritis (PM) has multiple factors contributing to its etiology, severity, and duration. It occurs during the period from calving to when the anterior pituitary gland becomes responsive to $\mathrm{GnRH}$ approximately 7 to $14 \mathrm{~d}$ postpartum (Olson et al., 1986). In PM, there is an inflammation of all layers of the uterus, and it is characterized by the presence of a fetid, watery reddish-brown vulvar discharge (Lewis, 1997). In some cases, PM is classified as a disease complex without distinguishing clinical severity or clinical presentation, making studies difficult to compare (Lewis, 1997). Sheldon et al. (2006) standardized the clinical definition of PM to include clinical symptoms such as decreased milk production, dullness, or other signs of toxemia with fever $\left(>39.5^{\circ} \mathrm{C}\right)$ within the first $21 \mathrm{~d}$ postpartum.

Prevention and early treatment of PM may be more economical than allowing the condition to progress. Yet, this assumption is difficult to evaluate because of cow welfare concerns that preclude having a negative control group with PM without treatment. Because of the effect of PM on health, early postpartum identification of PM by monitoring attitude and fever and treatment of cows with PM has been suggested (Upham, 1996). Rectal temperature (RT) is an indicator of core body temperature and is used as a diagnostic method to determine whether the cow has a fever. Fever is the result of a complex communication between the peripheral immune system and the brain in response to infection and inflammation, trauma, or 
both (Leon, 2002). Fever can be initiated by bacterial LPS acting directly as exogenous pyrogens or indirectly by infections that activate liver macrophages (Steiner et al., 2006) to produce endogenous pyrogens such as IL-6, IL-1, and tumor necrosis factor- $\alpha$ (Mackowiak et al., 1997).

It has been difficult to establish a minimum $\mathrm{RT}$ to define fever in postpartum health-monitoring protocols because of the broad range of $\mathrm{RT}$ described in the literature (Upham, 1996; Sheldon et al., 2004) and the multiple factors that affect RT (Rebhun, 1995). Kristula et al. (2001) evaluated postpartum RT: $48 \%$ of cows that calved normally had at least 1 daily RT above $39.1^{\circ} \mathrm{C}$, compared with $93,83,100$, and $78 \%$ for cows with retained placenta, mastitis, PM, and dystocia, respectively. They concluded that RT (per se) is not enough to determine whether antibiotic treatment is needed for postpartum cows.

Despite the common use of RT of postpartum cows as a monitoring tool, there is a lack of information on the value or significance of RT and calving status as tools to diagnose PM in dairy cows. Understanding the factors that predispose cows to PM and associated changes in RT should aid in the formulation of appropriate postpartum health-monitoring strategies.

The objectives of this study were as follows: 1) to evaluate the association among abnormal calving, parity, and season on the incidence of PM and clinical endometritis (CE) during d 3 to 13 and 20 to 30 postpartum, respectively; 2) to describe RT of cows with PM before diagnosis; and 3) to document associations among PM, CE, and reproductive performance in lactating dairy cows.

\section{MATERIALS AND METHODS}

\section{Cows and Herd Management}

The study was conducted from August 2002 to April 2003 in a commercial dairy farm in northeast Florida $\left(30^{\circ} 18^{\prime} \mathrm{N}, 81^{\circ} 56^{\prime} \mathrm{W}\right)$. The herd consisted of 1,000 lactating cows with a yearly rolling herd average for milk production of $9,165 \mathrm{~kg}$. The herd was milked 3 times daily and was a member of the DHIA (Raleigh, NC) with an on-farm computer-based record system.

Prepartum transition cows that were within 3 wk of calving were maintained on dry lots, fed a low DCAD diet, and monitored for signs of calving by farm employees trained to assist with parturition. Calving events such as dystocia, twins, and retained fetal membranes (RFM) were recorded by farm personnel. Dystocia was defined and recorded based on a 5-point scale as follows: 1) no assistance, 2) slight problem (assistance for $<15 \mathrm{~min}$ ), 3) needed assistance (assistance for $>15$ min with moderate difficulty for extraction),
4) considerable force used, and 5) extreme difficulty or veterinary assistance. Cows that did not expel the fetal membranes within $24 \mathrm{~h}$ after calving were considered to have RFM. Cows with dystocia delivered by cesarean section or fetotomy were not included in the study.

After parturition, cows were sent for $2 \mathrm{~d}$ to a hospital herd and housed on a concrete floor in an open-sided barn with stanchions that provided free access to a dirt lot. At the hospital barn, cows were treated according to standard operational procedures of the farm, which consisted of orally administering $60 \mathrm{~g}$ of $\mathrm{Ca}$ as $\mathrm{CaCl}_{2}$ paste (Super Calcium Gel; RXV, Kansas City, MO) to all multiparous cows and a single intrauterine infusion of $3 \mathrm{~g}$ of oxytetracycline dissolved in $75 \mathrm{~mL}$ of sterile water to cows with RFM. At $3 \mathrm{~d}$ postpartum, healthy cows were moved to a lactating herd kept in an open barn with dry compost and wood chips bedding and fed 4 times daily. Diets for both pre- and postpartum transition cows were a TMR formulated to meet or exceed the requirements of lactating dairy cows according to guidelines established by the NRC (2001).

The herd was maintained on a weekly reproductive herd health program provided by veterinarians from the University of Florida. Reproductive management began following a 60-d voluntary waiting period. After that, cows were identified in estrus by visual observation with the aid of tail chalk or neck activity meters (Westfalia-Surge Inc. Naperville IL). The cows were examined for pregnancy by palpation per rectum of the uterus and its contents at approximately $42 \mathrm{~d}$ from their last AI if they had not been detected in estrus after their last AI. Cows not receiving AI by $80 \mathrm{~d}$ postpartum were examined for evidence of cyclicity, and cows with a corpus luteum were treated with $25 \mathrm{mg}$ of $\mathrm{PGF}_{2 \alpha}$ intramuscularly (Lutalyse, Pfizer Animal Health, Kalamazoo, MI). Cows were AI at detected estrus. Cows without signs of ovarian activity were treated with $100 \mu \mathrm{g}$ of GnRH intramuscularly (Cystorelin, Merial Ltd., Iselin, NJ), followed $7 \mathrm{~d}$ later with an intramuscular injection of $\mathrm{PGF}_{2 \alpha}(25 \mathrm{mg})$ and subsequent $\mathrm{AI}$ at detected estrus. Cows not seen in estrus by $14 \mathrm{~d}$ after $\mathrm{PGF}_{2 \alpha}$ treatment were reexamined via palpation per rectum and treated with $\mathrm{PGF}_{2 \alpha}$ only if a corpus luteum was present. During weekly herd visits, cows that were not inseminated by $120 \mathrm{~d}$ postpartum and cows diagnosed not pregnant $>150 \mathrm{~d}$ postpartum were enrolled in the Ovsynch program (Pursley et al., 1995).

\section{Study Design}

This study followed a prospective observational study design. All cows underwent a postpartum 
health-monitoring program consisting of daily evaluation of RT and attitude from d 3 to 13 postpartum. Rectal temperature was determined with the use of a digital thermometer (GLA M500HPDT, Agricultural Electronics, San Luis Obispo, CA) from 0700 to $0900 \mathrm{~h}$ immediately after milking. Cows that either appeared sick (depressed and sunken, tented, or both, eyes) or had a $\mathrm{RT} \geq 39.4^{\circ} \mathrm{C}$ were examined for PM. The criterion for diagnosis of PM was the presence of a watery, brown, fetid discharge from the vulva, i.e., noted after palpation per rectum of the uterus, with or without a $\mathrm{RT} \geq 39.4^{\circ} \mathrm{C}$. Cows with a $\mathrm{RT} \geq 39.4^{\circ} \mathrm{C}$ and those that appeared sick regardless of $\mathrm{RT}$ and did not have a fetid vulvar discharge were evaluated on subsequent days and diagnosed with PM if they met the definition criterion.

All information concerning RT and incidence of PM was stored daily in a separate database belonging to the principal investigator. Cows diagnosed with PM were treated daily for $3 \mathrm{~d}$ with ceftiofur hydrochloride $(2.2 \mathrm{mg} / \mathrm{kg}$ intramuscularly; Excenel, Pfizer Animal Health, Kalamazoo, MI). In addition, supportive therapy consisting of antiinflammatory agents, $\mathrm{Ca}$, and energy supplements was administered. Cows that did not respond to the 3 -d ceftiofur treatment, based on the persistence of a fetid discharge, received an intrauterine infusion of $3 \mathrm{~g}$ of oxytetracycline diluted in 75 $\mathrm{mL}$ of sterile water.

All cows were examined for CE from 20 to $30 \mathrm{~d}$ postpartum. The criteria used to diagnose $\mathrm{CE}$ were the presence of 1 or more of the following conditions: cervical diameter $>6.0 \mathrm{~cm}$; asymmetry of the uterine horns with fluid content, pus, or both, present at the vulva following rectal manipulation of the uterus (Oltenacu et al., 1983). All examinations were performed by 2 experienced veterinarians. Cows diagnosed with $\mathrm{CE}$ were treated with a single injection of $25 \mathrm{mg}$ of $\mathrm{PGF}_{2 \alpha}$ (Lutalyse, Pfizer Animal Health) intramuscularly. Pregnancy diagnosis was determined by transrectal palpation of the uterus and its contents 42 to $49 \mathrm{~d}$ after AI.

\section{Data Management}

Data for parity and calving status (dystocia: calving score $\geq 3$, RFM, and twins) were recovered from the database, and 2 groups of cows were established based on calving status. Cows with a normal calving status (NC) were those without calving-related problems, and cows with an abnormal calving status (AC) were those with dystocia, RFM, twins, or some combination of these conditions. Cows were classified as having PM or not having it in a 2-level variable classified as metritis. Cows also were classified according to RT at diagnosis and presence or absence of PM, as a 3-level variable defined as Mettemp (MT): PM without fever (MT-1; RT $<39.4^{\circ} \mathrm{C}$ ), cows with PM and fever (MT-2; $\mathrm{RT} \geq 39.4^{\circ} \mathrm{C}$ ), and cows without PM (MT-3).

Cows were classified as primiparous or multiparous as a 2 -level variable classified as parity. The different seasons during the study were defined based on the temperature-humidity index [THI; THI $=\mathrm{td}-(0.55-$ 0.55RH) (td - 58); West, 1994). This THI index was calculated using daily ambient temperature (td) and percentage of relative humidity $(\mathrm{RH})$ recorded at the closest weather station at Macclenny, Florida $\left(30^{\circ} 24^{\prime}\right.$ $\mathrm{N}, 82^{\circ} 11^{\prime} \mathrm{W}$ ). Based on a previous report (West, 1994) a THI cutoff of 76.2 was used to define 2 seasons. A cold season was defined as those months with a mean THI of $<76.2$ (October to April) and a warm season as those months with a mean THI $\geq 76.2$ (May to September).

\section{Statistical Analyses}

All categorical outcome variables such as incidence of PM (\%), incidence of CE (\%), first-service conception risk (\%), cumulative pregnancy risk by $150 \mathrm{~d}$ postpartum (\%), and number of insemination for pregnant cows were analyzed using logistic regression PROC GENMOD of SAS 9.1 (SAS, 2003) with logit link and the appropriate distribution for dichotomous or count outcome variables.

The model used to analyze the incidence of PM or $\mathrm{CE}$ included the effects of calving status, parity, and season at calving. For the analysis on incidence of $\mathrm{CE}$, the variable PM was also included. A comparison on the incidence of CE among MT-1, MT-2, and MT-3 was analyzed by replacing the variable (metritis) with the variable MT.

Calving-to-first service intervals and calving-to-conception intervals by $150 \mathrm{~d}$ postpartum were analyzed with survival analysis using Cox's proportional hazards regression model (PROC PHREG, SAS Institute, 2003). The adjusted hazard ratios from the proportional hazards regression model are reported. Crude median days open reported on tables and survival function estimates used to generate graphics were obtained from the Kaplan-Meier analysis (PROC LIFETEST, SAS Institute, 2003).

All models for reproductive outcomes included the main effects of calving status, parity, season at first service, PM, and CE as explanatory variables. Modeling was performed using manual backward elimination starting from the more complex model with a third-order interaction, and the exclusion criteria were determined at $P>0.30$. The model fit statistics were performed by comparing the difference in the devi- 
ances by the likelihood-ratio statistic test. Adjusted odds ratios (AOR) and 95\% CI were determined.

Daily RT for the $5 \mathrm{~d}$ before and $5 \mathrm{~d}$ after diagnosis of cows with PM was compared with RT of cows without PM. Using a random number generator, 356 cows without PM were assigned to 94 cows with PM controlling by calving status, parity, and season. For cows with PM, days postpartum when PM was diagnosed were reclassified as follows: $\mathrm{d} 0$ as day of diagnosis; $\mathrm{d}$ $-1,-2,-3,-4,-5$ before diagnosis; and $\mathrm{d} 1,2,3,4$, 5 after diagnosis. Days postpartum were reclassified similarly for cows without PM. Therefore $d 0, d-1$ to -5 , and $\mathrm{d} 1$ to 5 for cows without PM corresponded with the same-day postpartum of cows with PM. This rearrangement of RT was done for a potential effect of days postpartum on RT.

The analysis of RT between cows with and without PM by day postpartum was performed using the PROC MIXED procedure for repeated measures of SAS 9.1 (SAS, 2003). The model was subjected to 4 covariate structures: compound symmetry, compound symmetry-heterogeneous, autoregressive order-1, and autoregressive order- 1 heterogeneous matrix. The autoregressive order-1 covariance structure had the smallest Akaike's information criterion and Schwarz's Bayesian criterion (Littell et al., 2002). Consequently, the covariate structure that specified a correlation structure within cows that decreased with increasing lag among measurements was used in the model. Two models were analyzed. The first model included the effects of calving status, PM, parity, season at calving, and day as main effects as well as the second- and third-order interactions among the main effects. The second model was analyzed by including the variable MT as a replacement for the variable metritis. The variable MT differentiates the daily RT of cows with $\mathrm{PM}$ and fever at diagnosis, cows with PM without fever at diagnosis, and cows without PM. Given that not all PM cases were diagnosed on the same day postpartum, the actual postpartum day at diagnosis was included in the model for both models.

The mixed model for repeated measures was defined as

$$
\begin{gathered}
\mathrm{Y}_{\mathrm{ijklmfg}}=\mu+\mathrm{G}_{\mathrm{i}}+\operatorname{Cow}\left(\mathrm{G}_{\mathrm{i}}\right)_{\mathrm{j}}+\text { Day }_{\mathrm{k}}+\text { Parity }_{\mathrm{l}}+\text { Season }_{\mathrm{m}} \\
+ \text { State }_{\mathrm{f}}+\text { Dmet }_{\mathrm{g}}+\left(\text { Day } \times \text { State }_{\mathrm{kf}}+\mathrm{e}_{\mathrm{ijklmfg}}\right.
\end{gathered}
$$

where $Y_{i j k l m f g}=$ daily rectal temperature; $G_{i}=$ fixed effect of calving status ( $\mathrm{NC}$ or $\mathrm{AC}) ; \operatorname{Cow}\left(\mathrm{G}_{\mathrm{i}}\right)_{j}=$ random effect of cow nested in calving status; Day $_{k}=$ fixed effect of time pre- and postdiagnosis; Parity $=$ fixed effect of parity; Season $_{\mathrm{m}}=$ fixed effect of season; State $_{\mathrm{f}}=$ fixed effect of PM (yes, no, or MT-1, MT-2, MT-3);
Dmet $_{\mathrm{g}}=$ fixed effect for DIM to puerperal metritis; $(\text { Day } \times \text { State })_{\mathrm{kf}}=$ fixed effect of interaction time and PM (yes, no, or MT-1, MT-2, MT-3); and $\mathrm{e}_{\mathrm{ijkl}} \mathrm{mfg}=$ random error term.

Differences among RT for the different days were determined by the use of the PDFF option of SAS. Least squares means $( \pm \mathrm{SEM})$ of $\mathrm{RT}$ were determined and illustrated in the graphics

\section{RESULTS}

A total of 488 cows were calved during the study period, and 38 cows were not included because they received antibiotic treatment beyond $3 \mathrm{~d}$ postpartum at the hospital barn and did not complete $10 \mathrm{~d}$ of health evaluation. Therefore, 450 calvings were evaluated, of which $327(73.0 \%)$ were classified as normal and 123 (27.0\%) as abnormal.

\section{Disease Incidence}

The overall incidence of PM was $21.0 \%$. Of 94 cows diagnosed with PM, 55 (58.5\%) were found without fever, and 39 (41.4\%) had fever at diagnosis. The logistic regression analysis showed that calving status was a risk factor for PM. Cows with an AC status had greater odds of PM than cows with NC status (AOR = $4.8 ; 95 \% \mathrm{CI}=2.9$ to 8.0 ). There was a significant season-by-parity interaction $(P<0.001)$. Primiparous cows that calved during the warm season had lower odds of PM than during the cold season $(\mathrm{AOR}=0.24$; $95 \% \mathrm{CI}=0.09$ to 0.62 ). Yet, multiparous cows did not have a seasonal effect on PM (AOR $=1.43 ; 95 \% \mathrm{CI}=$ 0.65 to 3.18; Table 1). Although there were a lower number of cows in the warm season for both parities, the marked differential occurrence of PM in the cold season for primiparous cows accounted for the season and parity interaction. A season effect on the risk for PM was not observed in multiparous cows. Still, with the low number of multiparous cows in summer, the power of the test for a slightly higher incidence of PM in the summer (18.1 vs. $11.0 \%$ ) was equal to $37.0 \%$.

The overall incidence of $\mathrm{CE}$ was $24.0 \%$. Cows with AC had greater odds of CE than cows with NC status $(\mathrm{AOR}=2.8 ; 95 \% \mathrm{CI}=1.7$ to $4.9 ; P<0.001)$. The odds of $\mathrm{CE}$ were greater in cows diagnosed with PM than in cows without $\mathrm{PM}(\mathrm{AOR}=2.2 ; 95 \% \mathrm{CI}=1.1$ to 3.9 ; $P<0.005$ ). Cows with PM categorized as MT-1 (AOR = $2.1 ; 95 \% \mathrm{CI}=1.09$ to $4.1 ; P<0.02)$ and MT-2 (AOR = $2.2 ; 95 \% \mathrm{CI}=1.07$ to $4.6 ; P<0.02)$ groups had greater odds of CE than cows without PM. Nonetheless, no differences between MT-1 and MT-2 on the odds of CE were detected (Table 2). 
Table 1. Incidence and risk factors of puerperal metritis in the first $13 \mathrm{~d}$ postpartum of lactating dairy cattle

\begin{tabular}{|c|c|c|c|c|c|}
\hline \multirow[b]{2}{*}{ Level } & \multicolumn{2}{|c|}{$\begin{array}{l}\text { Incidence of } \\
\text { puerperal } \\
\text { metritis }\end{array}$} & \multicolumn{2}{|c|}{$\begin{array}{c}\text { Risk of puerperal } \\
\text { metritis }\end{array}$} & \multirow[b]{2}{*}{$P$-value } \\
\hline & $\%$ & $\mathrm{n}$ & $\mathrm{AOR}^{1}$ & $95 \% \mathrm{CI}^{2}$ & \\
\hline \multicolumn{6}{|c|}{ Puerperal metritis ${ }^{3}$} \\
\hline Yes & 21.1 & 94 & - & - & - \\
\hline No & 79.1 & 356 & - & - & - \\
\hline Calving status ${ }^{4}$ & & & & & 0.001 \\
\hline Normal & 13.1 & $43 / 327$ & Referent & Referent & \\
\hline Abnormal & 41.4 & $51 / 123$ & 4.8 & 2.9 to 8.0 & \\
\hline Parity $\times$ season $^{5}$ & & & & & 0.001 \\
\hline \multicolumn{6}{|l|}{ Primiparous } \\
\hline Cold & 39.4 & $54 / 137$ & Referent & Referent & \\
\hline Warm & 12.7 & $6 / 47$ & 0.24 & 0.09 to 0.62 & \\
\hline \multicolumn{6}{|l|}{ Multiparous } \\
\hline Cold & 11.0 & $22 / 200$ & Referent & Referent & \\
\hline Warm & 18.1 & $12 / 66$ & 1.43 & 0.65 to 3.18 & \\
\hline
\end{tabular}

${ }^{1} \mathrm{AOR}=$ adjusted odds ratio.

${ }^{2} 95 \%$ CI $=95 \%$ confidence interval.

${ }^{3}$ Puerperal metritis = presence of a watery, brown-colored, fetid discharge from the vulva with or without a rectal temperature $\geq 39.4^{\circ} \mathrm{C}$ within $13 \mathrm{~d}$ postpartum.

${ }^{4}$ Abnormal calving status was cows with dystocia, retained fetal membrane, twins, or some combination of these conditions, and normal calving status was those cows without calving-related problems.

${ }^{5}$ Cold season was defined as those months with a mean temperature-humidity index (THI) of $<76.2$ and a warm season as those months with a mean THI $\geq 76.2$.

\section{RT Measurements}

The mean $( \pm \mathrm{SE})$, median, upper, and lower quartiles and the $95 \%$ CI for RT from d 3 through d 13 postpartum of cows with and without PM are shown in Table 3.

\section{All Cows With PM}

The analysis showed a significant interaction between day and PM $(P<0.001)$. Rectal temperature from cows with PM, i.e., cows with and without a fever

Table 2. Incidence and risk factors of clinical endometritis at 20 to $30 \mathrm{~d}$ postpartum of lactating dairy cattle

\begin{tabular}{|c|c|c|c|c|c|}
\hline \multirow[b]{2}{*}{ Level } & \multicolumn{2}{|c|}{$\begin{array}{l}\text { Incidence of } \\
\text { clinical } \\
\text { endometritis }\end{array}$} & \multicolumn{2}{|c|}{$\begin{array}{l}\text { Risk of clinical } \\
\text { endometritis }\end{array}$} & \multirow[b]{2}{*}{$P$-value } \\
\hline & $\%$ & $\mathrm{n}$ & $\mathrm{AOR}^{1}$ & $95 \% \mathrm{CI}^{2}$ & \\
\hline \multicolumn{6}{|l|}{ Clinical endometritis ${ }^{3}$} \\
\hline Yes & 24.0 & 108 & - & - & - \\
\hline No & 76.0 & 342 & - & - & - \\
\hline Calving status ${ }^{4}$ & & & & & 0.001 \\
\hline Normal & 17.7 & $58 / 327$ & Referent & Referent & \\
\hline Abnormal & 40.6 & $50 / 123$ & 2.8 & 1.7 to 4.9 & \\
\hline Parity & & & & & 0.07 \\
\hline Multiparous & 26.0 & $69 / 266$ & 1.0 & Referent & \\
\hline Primiparous & 23.3 & $43 / 184$ & 0.63 & 0.39 to 1.03 & \\
\hline \multicolumn{6}{|l|}{ Puerperal metritis $^{5}$} \\
\hline No metritis & 20.2 & $72 / 356$ & Referent & Referent & \\
\hline Puerperal metritis & 38.2 & $36 / 94$ & 2.2 & 1.1 to 3.9 & 0.005 \\
\hline MT-1 & 38.4 & $21 / 55$ & 2.1 & 1.09 to 4.1 & 0.02 \\
\hline MT-2 & 38.1 & $15 / 39$ & 2.2 & 1.07 to 4.6 & 0.02 \\
\hline
\end{tabular}

${ }^{1} \mathrm{AOR}=$ adjusted odds ratio.

${ }^{2} 95 \%$ CI $=95 \%$ confidence interval.

${ }^{3}$ Clinical endometritis = cervical diameter $>6.0 \mathrm{~cm}$; asymmetry of the uterine horns with fluid content, pus, or both, present at the vulva following rectal manipulation of the uterus within 20 to $30 \mathrm{~d}$ postpartum.

${ }^{4}$ Abnormal calving status was cows with dystocia, retained fetal membrane, twins, or some combination of these conditions, and normal calving status was those cows without calving-related problems.

${ }^{5}$ Puerperal metritis = presence of a watery, brown-colored, fetid discharge from the vulva with or without a rectal temperature $\geq 39.4^{\circ} \mathrm{C}$ within $13 \mathrm{~d}$ postpartum. MT- 1 = cows with puerperal metritis without fever; MT-2 = cows with puerperal metritis and fever. 
Table 3. Least squares means \pm SE, 25 th quartile, median, 75 th quartile, and population $95 \%$ confidence intervals (95\% CI) for rectal temperatures from d 3 through 13 postpartum of cows with and without puerperal metritis after adjusting for calving status, parity, and season.

\begin{tabular}{lccccc}
\hline Cow status & Mean $\pm \mathrm{SE}$ & $\begin{array}{c}\text { 25th } \\
\text { quartile }\end{array}$ & Median & $\begin{array}{c}\text { 75th } \\
\text { quartile }\end{array}$ & 95\% CI \\
\hline Normal calving $^{1}$ & $38.6 \pm 0.01$ & 38.3 & 38.5 & 38.8 & 37.7 to 39.4 \\
Abnormal calving $^{2}$ & $38.6 \pm 0.01$ & 38.3 & 38.6 & 39.0 & 37.5 to 39.6 \\
Cows without puerperal metritis $^{\text {Cows with puerperal metritis }}{ }^{3}$ & $38.6 \pm 0.01$ & 38.3 & 38.5 & 38.8 & 37.8 to 39.3 \\
MT-1 & $38.9 \pm 0.03$ & 38.4 & 38.7 & 39.1 & 37.4 to 40.3 \\
MT-2 & $38.7 \pm 0.04$ & 38.3 & 38.6 & 39.0 & 36.7 to 40.7 \\
\hline
\end{tabular}

${ }^{1}$ Normal calving status $=$ those cows without calving-related problems.

${ }^{2}$ Abnormal calving status $=$ cows with dystocia, retained fetal membrane, twins, or some combination of these conditions.

${ }^{3}$ Puerperal metritis = presence of a watery, brown-colored, fetid discharge from the vulva with or without a rectal temperature $\geq 39.4^{\circ} \mathrm{C}$ within $13 \mathrm{~d}$ postpartum. MT- $1(\mathrm{n}=55)=$ cows with puerperal metritis without fever; MT-2 $(\mathrm{n}=39)$ = cows with puerperal metritis with fever.

at diagnosis, was significantly higher at $72 \mathrm{~h}$ before the diagnosis of PM than in cows without PM, and RT continued to be different until d 4 after the diagnosis and treatment of PM (Figure 1).

Rectal temperature in cows diagnosed with PM increased linearly beginning at $-48 \mathrm{~h}$ before diagnosis of $\mathrm{PM}$ and reached a mean $\mathrm{RT}$ of $39.2 \pm 0.05^{\circ} \mathrm{C}$, which was greater than RT in cows without PM on d 0 (difference of $0.62 \pm 0.06^{\circ} \mathrm{C} ; P<0.001$ ). At $24 \mathrm{~h}$ before diagnosis, cows with PM had an increase in RT to the day of diagnosis (difference of $0.28 \pm 0.07^{\circ} \mathrm{C} ; P<0.001$ ). After treatment, $\mathrm{RT}$ of cows with $\mathrm{PM}$ had a reduction $(0.33$ $\pm 0.07^{\circ} \mathrm{C}, P<0.001$ ) by d 1 after treatment (Figure 1 ).

\section{PM Without (MT-1) and With (MT-2) Fever}

There was a significant interaction between day and MT classifications $(P<0.001)$. Rectal temperature

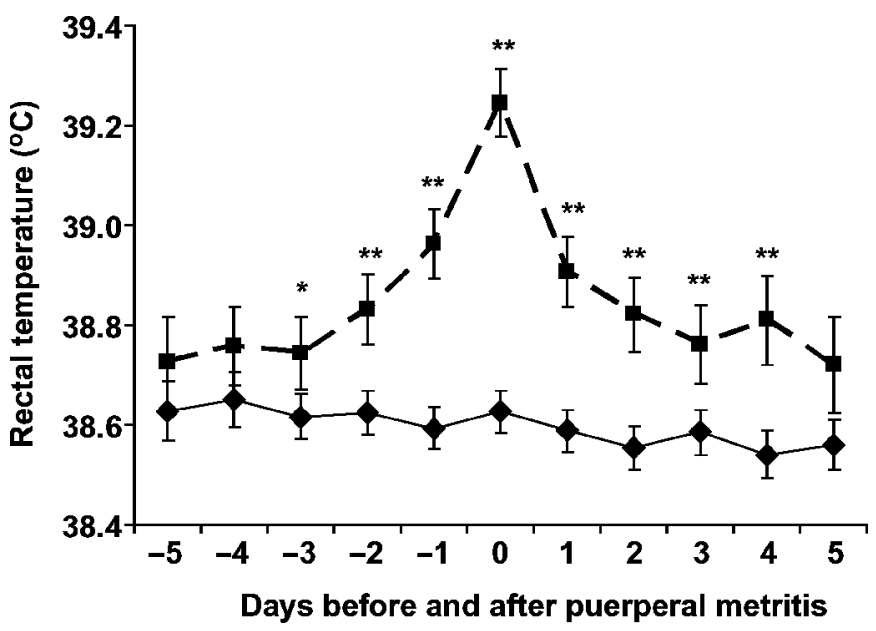

Figure 1. Least squares means \pm SEM of daily rectal temperatures of cows $5 \mathrm{~d}$ before and $5 \mathrm{~d}$ after the diagnosis of cows with puerperal metritis $(\mathrm{n}=94 ; \mathbf{\square})$ and cows without puerperal metritis $(\mathrm{n}=356$; ४). ${ }^{*} P<0.05 ; * * P<0.001$. from cows in the MT-2 group was significantly higher at $72 \mathrm{~h}$ before the diagnosis of PM than RT of cows in group MT-3. This difference continued to be significant until d 4 after the diagnosis and treatment of PM (Figure 2).

Within the MT-2 group, RT increased linearly beginning at $-48 \mathrm{~h}$ before diagnosis of PM and reached a mean RT of $39.7 \pm 0.09^{\circ} \mathrm{C}$, which was significantly greater than RT in the MT-3 group on d 0. At $24 \mathrm{~h}$ before diagnosis, cows in the MT-2 group had a significant increase in RT to the day of diagnosis (difference of $0.54^{\circ} \mathrm{C} \pm 0.07 \mathrm{C} ; P<0.001$ ). After treatment, cows in MT-2 showed a significant reduction in $\mathrm{RT}$ in the first $24 \mathrm{~h}\left(0.65 \pm 0.11^{\circ} \mathrm{C}, P<0.001\right)$. This reduction continued to be significant at $48 \mathrm{~h}$ after the diagnosis

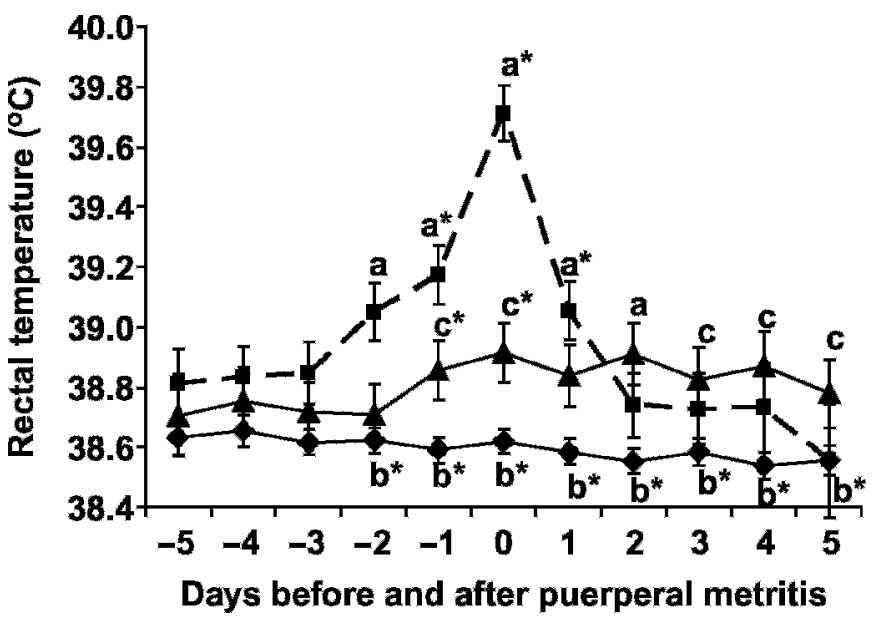

Figure 2. Least squares means \pm SEM of daily rectal temperatures of cows $5 \mathrm{~d}$ before to $5 \mathrm{~d}$ after diagnosis of puerperal metritis. Cows were classified as puerperal metritis and fever (MT-2, n = 39; $\mathbf{0}$ ), puerperal metritis without fever (MT-1, $\mathrm{n}=55 ; \mathbf{\Delta})$, and cows without puerperal metritis (MT-3, $\mathrm{n}=356$; $)$. Letters (a, b, c) differ with a $P<0.05$. $* P<0.005$. 
Table 4. Logistic regression model of first-service conception risk and cumulative pregnancy risk by $150 \mathrm{~d}$ postpartum by calving status, presence or absence of puerperal metritis, parity, season, and presence or absence of clinical endometritis

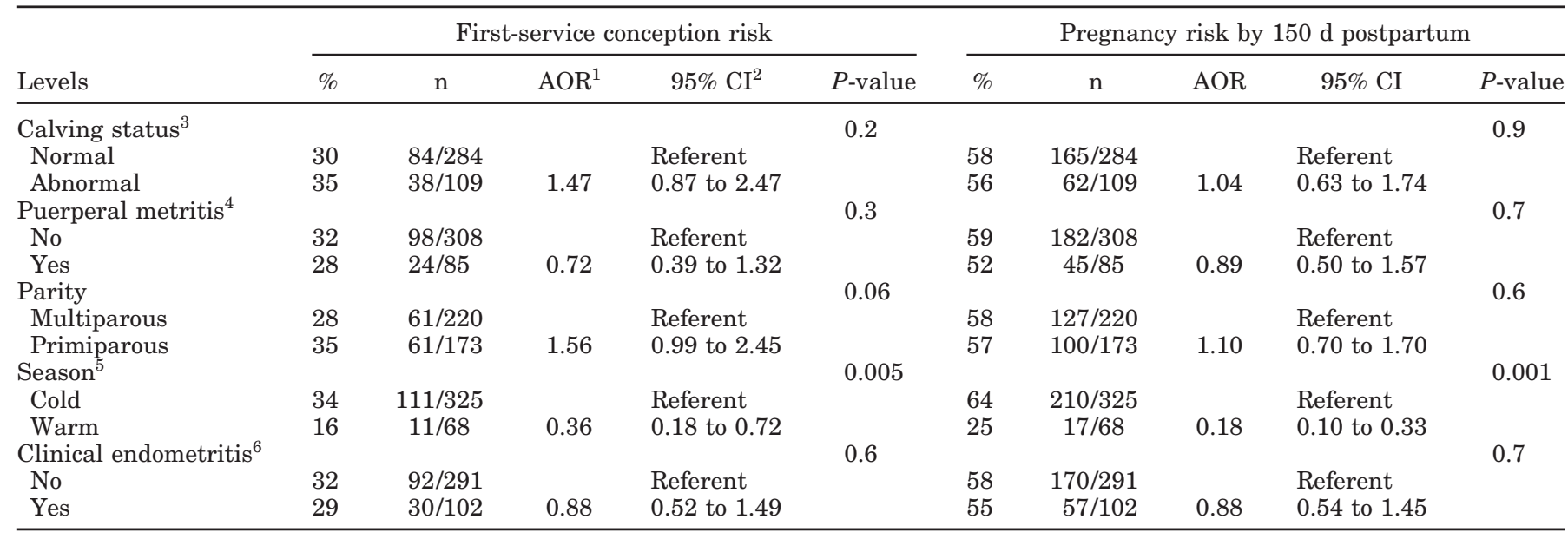

${ }^{1} \mathrm{AOR}=$ adjusted odds ratio.

${ }^{2} 95 \% \mathrm{CI}=95 \%$ confidence interval.

${ }^{3}$ Abnormal calving status was cows with dystocia, retained fetal membrane, twins, or some combination of these conditions, and normal calving status was those cows without calving-related problems.

${ }^{4}$ Puerperal metritis = presence of a watery, brown-colored, fetid discharge from the vulva with or without a rectal temperature $\geq 39.4^{\circ} \mathrm{C}$ within $13 \mathrm{~d}$ postpartum.

${ }^{5}$ Cold season was defined as those months with a mean temperature-humidity index (THI) of $<76.2$ and a warm season as those months with a mean THI $\geq 76.2$.

${ }^{6}$ Clinical endometritis = cervical diameter $>6.0 \mathrm{~cm}$; asymmetry of the uterine horns with fluid content, pus, or both, present at the vulva following rectal manipulation of the uterus within 20 to $30 \mathrm{~d}$ postpartum.

and treatment of $\mathrm{PM}$ (difference of $0.35 \pm 0.12^{\circ} \mathrm{C}, P$ $<0.01)$.

Daily RT for cows in the MT-1 group. i.e., PM without fever at diagnosis, was higher compared with RT in MT-3 at $24 \mathrm{~h}$ before the diagnosis and continued to be different until $\mathrm{d} 5$ after the diagnosis and treatment of PM. Within the MT-1 group, there was not a daily increase of RT before the diagnosis of PM. Cows diagnosed with PM in the absence of fever at diagnosis had an average $\mathrm{RT}$ of $38.9 \pm 0.08^{\circ} \mathrm{C}$ on $\mathrm{d} 0$, which was different from RT in the MT-3 group (difference of $\left.0.30 \pm 0.08^{\circ} \mathrm{C}, P<0.001\right)$. Though, there was not a significant reduction in the RT after the diagnosis and treatment of PM (Figure 2).

\section{Reproductive Variables}

There were no differences detected in first-service conception risk and accumulated pregnancy risk by $150 \mathrm{~d}$ postpartum for calving status, parity, PM, and $\mathrm{CE}$ (Table 4). On the other hand, the power of the respective tests ranged from 6 to $32 \%$. As expected, a seasonal effect was detected. Cows that calved during the warm season had lower odds to conceive at first service $(\mathrm{AOR}=0.98 ; 95 \% \mathrm{CI}=0.18$ to 0.72$)$ and by $150 \mathrm{~d}$ postpartum $(\mathrm{AOR}=0.18 ; 95 \% \mathrm{CI}=0.10$ to 0.33$)$ than cows calving during the cool season (Table 4).
No differences were observed on hazard of calvingto-first service intervals and calving-to-conception intervals by $150 \mathrm{~d}$ postpartum (Figure 3 ) for cows with or without PM (Table 5). Nevertheless, hazard of calving-to-first service intervals was affected by season and parity, whereas calving-to-conception intervals by $150 \mathrm{~d}$ postpartum were affected by season (Figure 4).

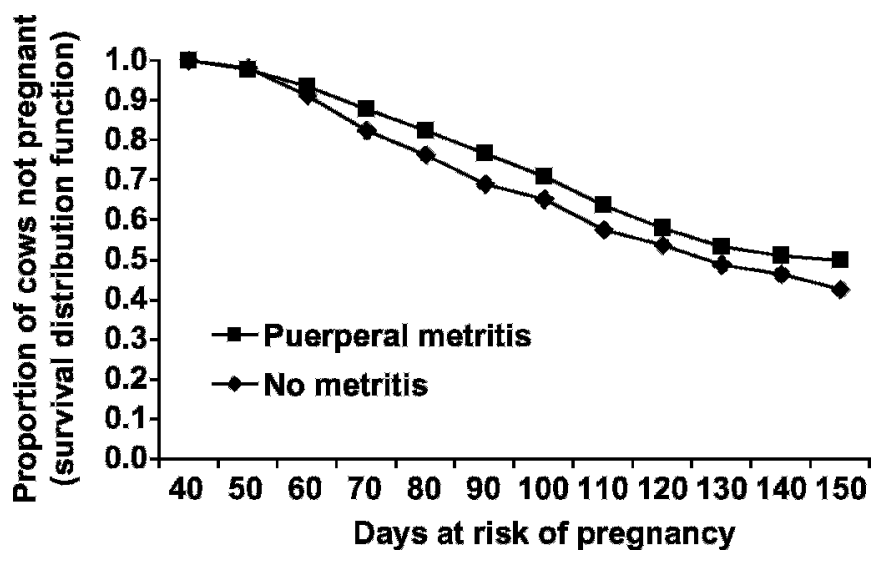

Figure 3. Survival function curves of calving-to-conception intervals by $150 \mathrm{~d}$ postpartum in cows with or without puerperal metritis. Puerperal metritis was defined as the presence of a watery, brown, fetid discharge from the vulva, i.e., noted after palpation per rectum of the uterus, with or without a rectal temperature $\geq 9.4^{\circ} \mathrm{C}$. 
RECTAL TEMPERATURE AND PUERPERAL METRITIS

Table 5. Proportional hazards regression model of calving-to-first service intervals and calving-to-conception intervals by $150 \mathrm{~d}$ postpartum by calving status, parity, season, and presence or absence of puerperal metritis and clinical endometritis

\begin{tabular}{|c|c|c|c|c|c|c|c|c|}
\hline Level & \multicolumn{4}{|c|}{ Calving to first service } & \multicolumn{4}{|c|}{ Calving to conception by $150 \mathrm{~d}$ postpartum } \\
\hline Calving status $^{3}$ & & & & 0.2 & & & & 0.9 \\
\hline Abnormal & $78.0 \pm 2.9$ & 0.83 & 0.66 to 1.05 & & $131.0 \pm 3.3$ & 1.01 & 0.81 to 1.27 & \\
\hline Puerperal metritis ${ }^{4}$ & & & & 0.7 & & & & 0.7 \\
\hline No & $70.0 \pm 1.7$ & & Referent & & $127.0 \pm 2.0$ & & Referent & \\
\hline Primiparous & $68.5 \pm 2.1$ & 1.37 & 1.21 to 1.69 & & $124.0 \pm 2.8$ & 0.97 & 0.80 to 1.18 & \\
\hline Season $^{5}$ & & & & 0.009 & & & & 0.001 \\
\hline Cold & $69.0 \pm 1.6$ & & Referent & & $117.0 \pm 1.9$ & & Referent & \\
\hline Warm & $83.0 \pm 4.0$ & 0.70 & 0.53 to 0.91 & & $127.0 \pm 3.1$ & 0.58 & 0.45 to 0.75 & \\
\hline Clinical endometritis ${ }^{6}$ & & & & 0.5 & & & & 0.7 \\
\hline No & $70.0 \pm 1.8$ & & Referent & & $127.0 \pm 2.0$ & & Referent & \\
\hline
\end{tabular}

${ }^{1}$ Hazard $=$ adjusted hazard ratio.

${ }^{2} 95 \% \mathrm{CI}=95 \%$ confidence interval.

${ }^{3}$ Abnormal calving status was cows with dystocia, retained fetal membrane, twins, or some combination of these conditions, and normal calving status was those cows without calving-related problems.

${ }^{4}$ Puerperal metritis = presence of a watery, brown-colored, fetid discharge from the vulva with or without a rectal temperature $\geq 39.4^{\circ} \mathrm{C}$ within $13 \mathrm{~d}$ postpartum.

${ }^{5}$ Cold season was defined as those months with a mean temperature-humidity index (THI) of $<76.2$ and a warm season as those months with a mean THI $\geq 76.2$.

${ }^{6}$ Clinical endometritis $=$ cervical diameter $>6.0 \mathrm{~cm}$; asymmetry of the uterine horns with fluid content, pus, or both, present at the vulva following rectal manipulation of the uterus within 20 to $30 \mathrm{~d}$ postpartum.

Cows with PM had 6.0\% more inseminations per pregnancy than cows without PM. Though, this difference was not significant.

\section{DISCUSSION}

\section{Disease Incidence}

Cows with dystocia, RFM, twins, or some combination of these conditions had an AC. These disorders

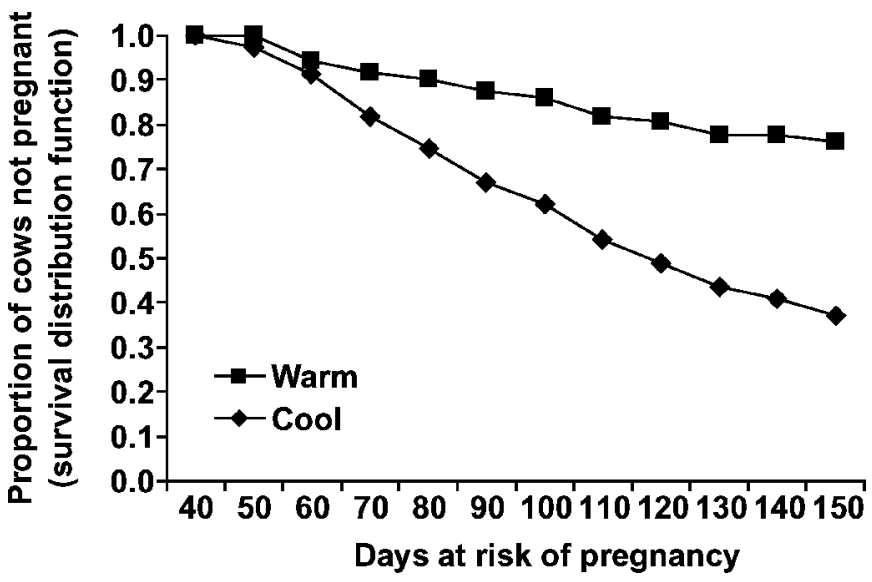

Figure 4. Survival function curves of calving-to-conception intervals by $150 \mathrm{~d}$ postpartum during warm and cool breeding season. A cool season was defined as those months with a mean temperaturehumidity index (THI) of $<76.2$ (October to April) and a warm season as those months with a mean THI $\geq 76.2$ (May to September). were risk factors for metritis in dairy cows (Markusfeld, 1984; Correa et al., 1993). It was not the intent of this study to determine the individual effect of these disorders on the incidence of PM. Instead, we considered cows with 1 or more of these disorders as a highrisk group for developing PM and retrospectively compared the incidence of PM to a low-risk group (cows with a NC). The clinical approach used to identify cows evaluated for PM was based on evaluation of attitude (appeared sick) or a $\mathrm{RT} \geq 39.4^{\circ} \mathrm{C}$. Despite not having a systematic examination of the uterus of all cows, the incidence of PM (42.0\%) in cows with an AC was similar to Markusfeld (1984).

The definition of PM used in the present study was based on a diagnosis by per rectum palpation of the uterus and visual inspection of the vulva to observe the presence of a fetid vulvar discharge with or without fever. This method of diagnosis of PM was described previously (Markusfeld, 1984). Of the cows with PM, only $41.4 \%$ had a fever.

Primiparous cows in the present study had a higher incidence of PM during the cold season. Yet, no seasonal effect was observed in multiparous cows. Effects of season and parity on the incidence of postpartum uterine infections have been described previously (Markusfeld, 1984; Smith et al., 1998). Still, an interaction between these 2 factors was not reported. Markusfeld (1984) hypothesized that during the winter 
months, a high concentration of calving and a wet and dirty environment may increase the challenge of pathogens to the uterine environment. Still, in the present study, both primiparous and multiparous cows were equally exposed to these factors.

The overall incidence of $\mathrm{CE}$ is in agreement with that observed by LeBlanc et al. (2002). Hirvonen et al. (1999) reported that cows diagnosed with PM (putrid smelling, reddish-brown, watery vaginal discharge; $\mathrm{RT}$ of 39.5 to $41.0^{\circ} \mathrm{C}$; within 4 to $11 \mathrm{~d}$ postpartum) had purulent vaginal discharges of 58 and $6 \%$ from 15 to 22 and 32 to $44 \mathrm{~d}$ postpartum, respectively. In the present study, the incidence of CE $(38.2 \%)$ in cows with PM and treated with ceftiofur was similar to that observed by Drillich et al. (2001). In the latter study, $44.8 \%$ of the cows with PM and treated with ceftiofur hydrochloride developed $\mathrm{CE}$ within 32 to $34 \mathrm{~d}$ postpartum. An interesting finding in our study was that cows with PM developed CE whether or not they had fever when PM was diagnosed. This may suggest that despite treatment of PM, cows without fever were just as likely as those with fever to develop CE.

\section{Cow Rectal Temperature}

Based on a previous report (Upham, 1996), the present study defined fever to be a $R T \geq 39.4^{\circ} \mathrm{C}$. Normal $\mathrm{RT}$ have been reported within the range of 38.0 to $39.1^{\circ} \mathrm{C}$ (Rebhun, 1995), and cows with a RT above the upper limit were defined as febrile or abnormal. Sheldon et al. (2004) reported a mean RT during the first $10 \mathrm{~d}$ postpartum of $38.7^{\circ} \mathrm{C}$ for cows without RFM. In the present study, the mean $\mathrm{RT}\left(38.6^{\circ} \mathrm{C}\right)$ for cows without PM and classified as normal was within the above described range and in agreement with that reported by Kristula et al. (2001) and Sheldon et al. (2004).

\section{All Cows With PM}

Daily increases of RT before diagnosis of PM have not been reported. Rectal temperature of cows with PM started increasing $2 \mathrm{~d}$ before the diagnosis of PM. The RT on $\mathrm{d} 0$ (diagnosis of PM) did not reach a predefined febrile level of $39.4^{\circ} \mathrm{C}$ and was similar to those reported in cows with PM (Smith et al., 1998). This is probably due to the proportion of cows with PM on d 0 that did not have a fever. Following treatment of cows with PM, RT decreased to a level similar to cows without PM that were not treated. Similar responses in $\mathrm{RT}$ reduction have been observed in cows with PM treated with ceftiofur (Smith et al., 1998).

\section{PM Without (MT-1) and With (MT-2) Fever}

Two different patterns of RT for the different classifications of PM were observed. Cows classified as MT-
2 showed a gradual increase in $\mathrm{RT}$ with a marked increase $24 \mathrm{~h}$ before diagnosis, and this elevated RT was rapidly reduced after diagnosis and treatment. In contrast, this abrupt pattern was not observed in cows classified as MT-1. Physiological control of a febrile response is multifactorial with mechanisms to prevent extreme elevation in body temperature (Leon, 2002). Our results showed that RT of cows with PM and fever had daily increases of RT to a point in which they became febrile. This may occur from the interaction between the host immune system and bacterial endotoxins that trigger the cascade of events that lead to elevated temperature. The systemic release of prostaglandin $\mathrm{E}_{2}$ could be a mediator of fever (Mackowiak et al, 1997).

The reason why a proportion of cows did not have fever when PM was diagnosed or why they did not experience an increase in RT before PM diagnosis is unknown. Still, because all cows with PM without fever were treated on the same day of diagnosis, a lack of disease progression may have occurred. It is possible that these cows were under a septic process with higher blood concentrations of LPS than cows with fever. Fever induced by LPS seems dose-related in that a high dose of LPS lowers body temperature, attenuates fever, and causes hypothermia. In contrast, lower doses of LPS stimulate the production of tumor necrosis factor with subsequent production of fever (Leon, 2002). Alternatively, cows with high concentrations of blood LPS could have been hypocalcemic and thus were unable to generate enough heat to produce fever. The data in Figures 1 and 2 indicate RT is significantly increased before diagnosis of PM. Fever is a response of the animal to an infection, which is related to PM. The degree of a RT increase can vary in cows with PM (Figure 2). Consequently, treatment consideration should be based on the condition of the uterus (PM) and not necessarily on concurrent presence of a RT $\geq 39.4^{\circ} \mathrm{C}$.

The present study identified cows with PM that did not have a classical fever of $39.4^{\circ} \mathrm{C}$. It is conceivable that the classical definition of a fever $\left(39.4^{\circ} \mathrm{C}\right)$ is not appropriate for a diagnosis of metritis that includes clinical symptoms. In the study by Sheldon et al. (2004), the cut-off point used to define the categories of pyrexia and normal RT was set as the 75th quartile of the maximum RT. Utilizing that rationale, they found that the 75th quartile of maximal RT recorded during a 10-d postpartum period for normal and RFM cows was equal to $39.7^{\circ} \mathrm{C}$. Utilizing a more conservative approach with 356 cows that did not develop PM and using all daily temperatures for a 13 -d period, the 75th quartile in this study was $38.8^{\circ} \mathrm{C}$. Consequently, a RT of $>38.8^{\circ} \mathrm{C}$ could be considered as a potential RT 
warranting further clinical evaluation for PM. Indeed, cows diagnosed with PM and a classical fever (M-2) had an upper quartile RT of $39.4^{\circ} \mathrm{C}$, and cows diagnosed with PM without a classical fever (M-1) had a 75 th quartile $\mathrm{RT}$ of $39.0^{\circ} \mathrm{C}$. Thus, the critical temperature for possible identification of cows evaluated for $\mathrm{PM}$ would be a $\mathrm{RT}>38.8^{\circ} \mathrm{C}$.

\section{Reproductive Performance}

Farm personnel involved in conducting the reproductive management were blind to the calving or PM status of the cows. Abnormal calving, PM, or CE did not have a significant effect on reproductive performance. The differences in first-service conception risk or accumulated pregnancy risk by $150 \mathrm{~d}$ postpartum between cows with or without PM were not statistically different (i.e., 4 and 7\%, respectively).

Rectal examination of postpartum cows has been implemented during the first $10 \mathrm{~d}$ postpartum (Upham, 1996). In the present study, the intensity of the postpartum health-monitoring program may have resulted in an earlier diagnosis and treatment of PM and CE. A meta-analysis study on the effect of disease on reproduction (Fourichon et al., 2000) showed less effects of PM in studies reporting routine examination of cows compared with herds in which the owner reported the disease. In addition, Harman et al. (1996) did not find any effect of cows with dystocia, RFM, or early metritis during 56 to $120 \mathrm{~d}$ postpartum on the risk of conception. All cows with $\mathrm{CE}$ in the present study were treated with a single injection of $25 \mathrm{mg}$ of $\mathrm{PGF}_{2 \alpha}$. Cows were treated with a single dose of $\mathrm{PGF}_{2 \alpha}$ in cases of nonobserved estrus. Consequently, it is possible that cows affected with CE may have recovered sufficiently such that there was no alteration in reproductive performance (Table 4). The use of $\mathrm{PGF}_{2 \alpha}$ during the early postpartum period improved fertility in cows that experienced an AC (Risco et al., 1994).

Results of the present study clearly show the classical effects of seasonal heat stress on fertility. Still, the present study indicates that cows presented to first service during the warm season have an extended period of nonpregnancy throughout the subsequent 150 $\mathrm{d}$ of the insemination period (Figure 4). Whether this relationship would be further exacerbated for cows having a greater incidence of undetected PM during the warm season that are not treated warrants further investigation.

\section{CONCLUSIONS}

Cows experiencing an AC had greater odds of PM than those with NC status. Primiparous cows had greater odds of PM in the cold season, and multiparous cows showed no seasonality in the occurrence of PM. Cows with AC or PM had greater odds of CE. Despite treatment of PM, cows without fever were just as likely as those with fever to develop CE.

Evaluation of daily RT distinguished cows with PM with or without fever. A high proportion of cows did not have fever at the time PM was diagnosed, indicating that PM is not always accompanied by a fever. Before diagnosis, daily increases in RT on 2 consecutive days before the actual diagnosis could serve as a predictor of PM in cows that subsequently develop a fever at the time PM is diagnosed. Diagnostic and treatment consideration for PM should include the attitude of the cow and the condition of the uterus and not RT alone.

In cows diagnosed with PM and treated, first-service conception risk and cumulative pregnancy risks by 150 d postpartum were comparable to cows with $\mathrm{NC}$ or $\mathrm{AC}$ status that did not experience PM.

\section{ACKNOWLEDGMENTS}

We thank Ingo Krieg, Mecklenburg Dairy, Jacksonville, Florida, for providing cows and support and to Roger Rowe and staff of Mecklenburg Dairy for assistance. This research was supported by a grant from the Florida Dairy Milk Check-Off Program.

\section{REFERENCES}

Correa, M. T., H. Erb, and J. Scarlett. 1993. Path analysis for seven postpartum disorders of Holstein cows. J. Dairy Sci. 76:13051312 .

Drillich, M., O. Beetz, A. Pfutzner, M. Sabin, H. J. Sabin, P. Kutzer, H. Nattermann, and W. Heuwieser. 2001. Evaluation of a systemic antibiotic treatment of toxic puerperal metritis in dairy cows. J. Dairy Sci. 84:2010-2017.

Fourichon, C., H. Seegers, and X. Malhe. 2000. Effect of disease on reproduction in the dairy cow: A meta-analysis. Theriogenology 53:1729-1759.

Harman, J. L., Y. T. Gröhn, H. N. Erb, and G. Casella. 1996. Eventtime analysis of the effect of season of parturition, parity, and concurrent disease on parturition-to-conception interval in dairy cows. Am. J. Vet. Res. 57:640-645.

Hirvonen, J., G. Huszenicza, M. Kulcsar, and S. Pyorala. 1999. Acute-phase response in dairy cows with acute postpartum metritis. Theriogenology 51:1071-1083.

Kristula, M., B. I. Smith, and A. Simeone. 2001. The use of daily postpartum rectal temperature to select dairy cows for treatment with systemic antibiotics. Bovine Pract. 35:117-125.

LeBlanc, S. J., T. F. Duffield, K. E. Leslie, K. G. Bateman, G. P. Keefe, J. S. Walton, and W. H. Johnson. 2002. Defining and diagnosing postpartum clinical endometritis and its impact on reproductive performance in dairy cows. J. Dairy Sci. 85:2223-2236.

Leon, R. L. 2002. Invited review: Cytokine regulation of fever: Studies using gene knockout mice. J. Appl. Physiol. 92:2648-2655.

Lewis, G. S. 1997. Uterine health and disorders. J. Dairy Sci. 80:984-994.

Littell, R. C., W. W. Stroup, and R. J. Freund. 2002. SAS for Linear Models. 4th ed. SAS Institute Inc., Cary, NC. 
Mackowiak, P. A., J. G. Bartlett, E. C. Borden, S. E. Goldblum, J. D. Hasday, R. S. Munford, S. A. Nasraway, P. D. Stolley, and T. E. Woodward. 1997. Concept of fever: Recent advances and lingering dogma. Clin. Infect. Dis. 25:119-138.

Markusfeld, O. 1984. Factors responsible for post parturient metritis in dairy cattle. Vet. Rec. 114:539-542.

National Research Council. 2001. Nutrient Requirements of Dairy Cattle. 7th rev. ed. Natl. Acad. Sci., Washington, DC.

Olson, J. D., K. N. Bretzlaff, R. G. Mortimer, and L. Ball. 1986. The metritis-pyometra complex. Pages 227-236 in Current Therapy in Theriogenology 2: Diagnosis, Treatment and Prevention of Reproductive Diseases in Small and Large Animals. W. B. Saunders Co., Philadelphia, PA.

Oltenacu, P. A., J. H. Britt, R. K. Braun, and R. W. Mellenberger. 1983. Relationships among type of parturition, type of discharge from genital tract, involution of cervix, and subsequent reproductive performance in Holstein cows. J. Dairy Sci. 66:612-619.

Pursley, J. R., M. O. Mee, and M. C. Wiltbank. 1995. Synchronization of ovulation in dairy cows using $\mathrm{PGF}_{2 \alpha}$ and $\mathrm{GnRH}$. Theriogenology 44:915-923.

Rebhun, W. C. 1995. Diseases of Dairy Cattle. Lippincott Williams \& Wilkins, Baltimore, MD.

Risco, C. A., L. F. Archbald, J. Elliott, T. Tran, and P. Chavatte. 1994. Effect of hormonal treatment on fertility in dairy cows with dystocia or retained fetal membranes at parturition. J. Dairy Sci. 77:2562-2569.

SAS. 2003. SAS/STAT Software for Windows 9.1. SAS Inst. Inc., Cary, NC.

Sheldon, I. M., G. S. Lewis, S. Leblanc, and R. O. Gilbert. 2006. Defining postpartum uterine disease in cattle. Theriogenology 65:1516-1530.

Sheldon, I. M., A. N. Rycroft, and C. Zhou. 2004. Association between postpartum pyrexia and uterine bacterial infection in dairy cattle. Vet. Rec. 154:289-293.

Smith, B. I., G. A. Donovan, C. A. Risco, R. Littell, C. Young, L. H. Stanker, and J. Elliott. 1998. Comparison of various antibiotic treatments for cows diagnosed with toxic puerperal metritis. J. Dairy Sci. 81:1555-1562.

Steiner, A. A., S. Chakravarty, A. Y. Rudaya, M. Herkenham, and A. A. Romanovsky. 2006. Bacterial lipopolysaccharide fever is initiated via Toll-like receptor 4 on hematopoietic cells. Blood 107:4000-4002.

Upham, G. L. 1996. A practitioner's approach to management of metritis/endometritis: Early detection and supportive treatment. Proc 29th Annu. Conv. Am. Assoc. Bovine. Pract., San Diego, CA. Frontier Printers Inc., Stillwater, OK.

West, J. W. 1994. Interactions of energy and bovine somatotropin with heat stress. J. Dairy Sci. 77:2091-2102. 